\title{
PERANCANGAN DAN SIMULASI PEMISAHAN REFRAIN LAGU DENGAN METODE FAST FOURIER TRANSFORM (FFT)
}

\author{
Obed Simanungkalit ${ }^{1}$, Rita Magdalena ${ }^{2}$, I Nyoman Apraz Ramatryana ${ }^{3}$ \\ ${ }^{1,2,3}$ Fakultas Teknik Elektro, Universitas Telkom \\ 1obedsimanungkalit@gmail.com, \\ ${ }^{2}$ ritamagdalena@telkomuniversity.ac.id, ${ }^{3}$ ramatryana@telkomuniversity.ac.id
}

\begin{abstract}
Abstrak
Pemisahan reff lagu secara manual untuk sebuah database membutuhkan waktu yang sedikit lama.Hal ini disebabkan untuk menentukan semua posisi reff dalam sebuah lagu, seseorang harus mengetahui lagu tersebut dengan mendengarkan lagu secara keseluruhan. Penelitian ini mengusulkan sistem penambahan database otomatis secara cepat dan tepat dengan memanfaatkan perkembangan audio processing dalam industri musik. Kami membuat sistem dengan menggunakan lagu sebagai input dilengkapi dengan ekstraksi ciri menggunakan metode Fast Fourier Transform (FFT).Kemudian sistem akan melakukan pencocokan data antara potongan reff pertama lagu yang sudah diketahui posisinya dengan lagu tersebut secara utuh.Hal ini dilakukan untuk mendapatkan output berupa posisi reff kedua dan ketiga dalam sebuah lagu. Penggunaan metode FFT pada makalah ini diharapkan memiliki akurasi tinggi dan waktu komputasi yang baik.
\end{abstract}

Kata Kunci: pemisahan reff, FFT

\begin{abstract}
Splitting the song reff for a database manually takes a little time. This is because to define all the reff positions in a song, one must know the song by listening to the song as a whole. This paper proposes automatic database creation system of songs quickly and correctly based on the current development of audio processing for digital music industries. System is made with songs as input combined with a feature of extraction using Fast Fourier Transform (FFT).Then the system will perform data matching between the first reff pieces of a known song to its position with the song in full. This is done to get the output of the position Second and third reff in a song. The proposed method is expected to have high accuracy and short computational time.
\end{abstract}

Keywords: separating reff, FFT

1. Pendahuluan

Musik merupakan bahasa universal karena musik tidak membeda-bedakan pendengarnya, dan pesan yang terdapat dalam musik akan lebih mudah diterima oleh semua kalangan masyarakat. Semua masyarakat bisa menikmati musik dimana saja dan kapan saja seperti di laptop, telepon seluler, kafe, kantor dan lainnya. Perkembangan industri musik saat ini sangatlah pesat, ditandai dengan kemunculan musik yang berbentuk lagu-lagu baru baik dalam negeri maupun luar negeri sehingga koleksi lagu bagi penikmatnya akan bertambah banyak.

Pada penelitian sebelumnya dirancang analisis dan simulasi klasifikasi judul lagu dari senandung manusia menggunakan ekstrasi ciri Fast FourierTransform (FFT) [1].

Namun sistem tersebut terbatas dalam penambahan database dimana lagu-lagu yang disimpan di dalam database dipisahkan secara manual pada bagian reffnya. Pada penelitian ini dilakukan sistem penambahan database secara otomatis untuk memperbanyak lagu-lagu pada database secara cepat dan tepat. Denganmemanfaatkan perkembangan dari audio processing yang banyak membantu dalam perkembangan industri musik digital. Sistem yang akan dibuat menggunakan lagu sebagai input yang kemudian dilakukan ekstraksi ciri menggunakan FFT.

Diharapkan pengunaan metode pada penelitian ini dapat menghasilkan akurasi yang tinggi serta waktu komputasi yang baik. Output yang diharapkan adalah berupa potongan lagu yang berasal dari reff lagunya. 


\section{Dasar Teori dan Perancangan system}

\subsection{Reff Lagu}

Reff/Refrain yang berarti pengulangan biasanya menggunakan bagian lain dari lagu (verse) untuk diulang dibagian ini. Notasi pengulangan dan syair sama, terkadang syair juga dimodifikasi, tetapi notasi atau nada tetap menggunakan nada yang sama [3].

\subsection{Fast Fourier Transform (FFT)}

FFT adalah metode yang sangat efisien untuk menghitung koefisien dari fourier diskrit ke suatu finitesequence dari data yang kompleks. Fourier diskritadalah bentuk domain waktu sebuah sinyal, sedangkan finitesequence bentuk domain frekuensi sinyal yang diubah dari domain waktu.Fast FourierTransform (FFT) merupakan aplikasi temuan yangpenting di dalam sejumlah bidang yang berbeda seperti analisis spectrum, speech and optical signalprocessing, design filterdigital.Algoritma FFT berdasarkan atas prinsip pokok dekomposisi perhitungan discrete fourier transform dari suatu sequence sepanjang $\mathrm{N}$ kedalam transformasi diskrit Fourier secara berturut-turut lebih kecil. Cara prinsipini diterapkan memimpin kearah suatu variasi darialgortima yangberbeda,yang semuanya memperbandingkan peningkatan kecepatan perhitungan $[1,2]$.

Gambar 1. merupakan contoh sinyal dalam domain waktu yang kemudian diubah ke dalam domain frekuensi pada gambar 2. dengan menggunakan ekstraksi ciri FFT.

\subsection{Perancangan Sistem}

Secara keseluruhan blok diagram tahapan dari proses perancangan sistem direpresentasikan sebagai berikut: Gambar 3 Blok Diagram Sistem.

Dalam perancangan sistem ini terdapat 3 tahapan penting yang digambarkan pada sistem ini yang pertama pre-processing blok ini bertujuan untuk memperbaiki kualitas data sebelum dilakukan ekstraksi ciri terdiri dari filtering, resample, convertstereo to mono.Setelah dilakukan pre-processing,selanjutnya lagu diproses pada blok ekstraksi ciri yang kemudian diambil cirinya menggunakan ekstraksi ciri FFT, metode ini mengubah sinyal lagu dalam domain waktu ke domain frekuensi.

Kemudian sistem akan melakukan pencocokan data antara potongan reff pertama lagu dengan lagu secara utuh untuk mendapatkan posisi reff kedua dan ketiga.

\subsection{Alur Kerja Sistem}

Alur kerja sistem dibuat dengan tujuan untuk mempermudah dalam pembuatan sistem pada penelitian ini. Berikut alur kerja sistem yang secara umum pada sistem pemisahan reff secara langsung.

Data input lagu berupa 10 data lagu instrument dan 20 lagu dengan 4 genre yang berbeda. Data lagu dan diproses untuk menghasilkan ciri masing-masing, hasil ekstraksi ciri pada data lagu dijadikan sebagai data yang kemudian sebagai acuan untuk diidentifikasi. Proses selanjutnya mengidentifikasi data lagu dengan menggunakan metode autokorealsi yaitu menentukan jarak terdekat antara perulangan lagu, sehingga diperoleh kecocokan jarak terdekat dari bagian lagu (reff) yang sesuai.

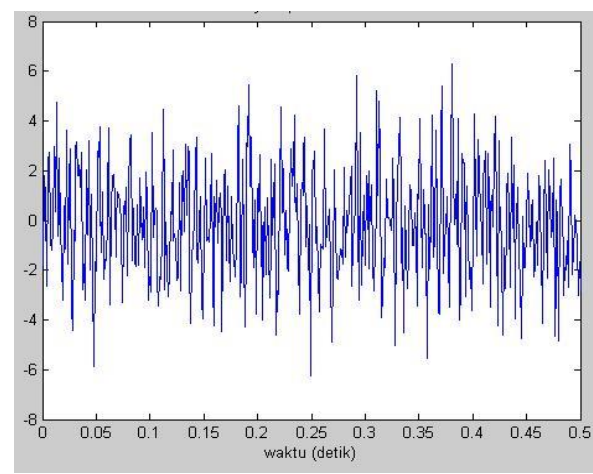

Gambar 1. Domain Waktu

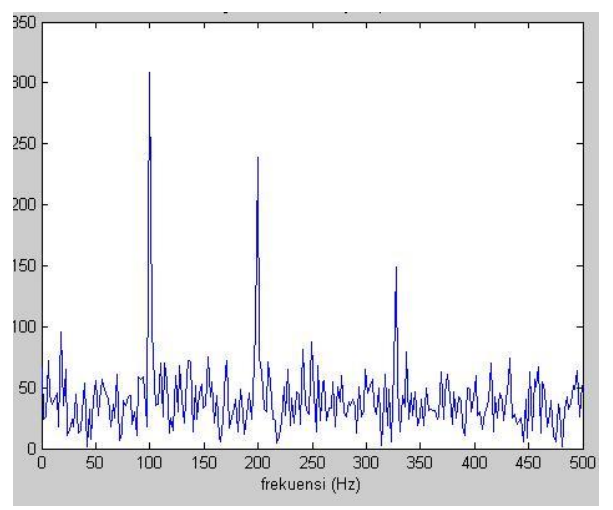

Gambar 2. Domain Frekuensi

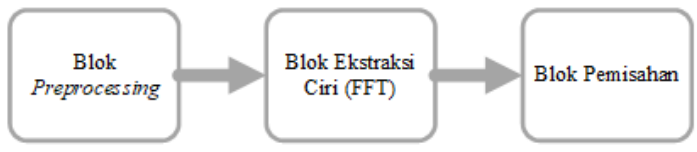

Gambar 3. Blok Diagram Sistem 


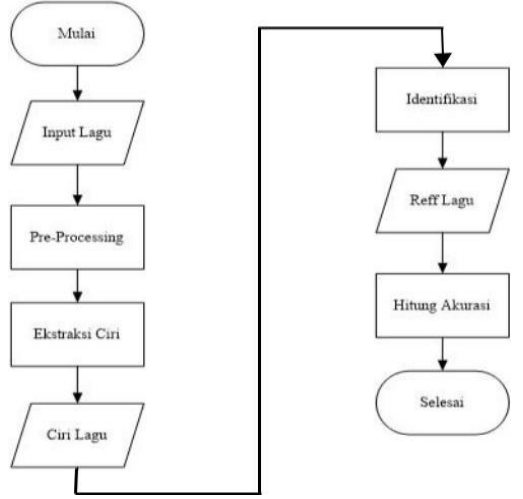

Gambar 4. Alur Kerja Sistem

\subsection{Flowchart Pre-Processing}

Setelah pengambilan data selesai, maka proses berikutnya yaitu pre-processing. Tahapan ini bertujuan untuk memperbaiki kualitas data sebelum masuk ke tahap ekstraksi ciri. Adapun tahapan yang dilakukan dalam pre-processing yaitu sebagai berikut:

- Filtering: Tahap pertama pada preprocessingadalah data di filter untuk meredamderau/sinyal selain input lagu yang diteliti. Untuk membuat filter tersebut diperlukan perancangan filter digital IIR (Infinite Impulse Response).Filter ini digunakan untuk mendapatkan rentang frekuensi $300-3400 \mathrm{~Hz}$ dikarenakan frekuensi suara manusia berada pada rentang 20-20000Hz.

- Resample: Pada tahap ini data akan disampling ulang untuk mempersingkat kerja sistem dengan frekuensi sampling yang lebih sedikit dari frekuensi sampling aslinya. Pada tahap ini dilakukan perubahan ukuran frame untuk melihat nilai akurasi terbaik. Berdasarkan teorema Nyquist, frekuensi sampling $\geq 2 *$ frekuensi input maksimum.

- $\quad$ Stereo to Mono: Pada tahap ini data akan diubah dari stereo ke mono dengan mencari nilai rata-rata kedua kanal pada data stereo untuk diubah menjadi satu kanal saja (mono). Maksudnya adalah data sinyal yang sebelumnya terdiri dari dua buah matriks akan diubah menjadi satu matriks dengan cara menghitung rata-rata sinyal pada tiap titik yang sama.

\subsection{Ekstraksi Ciri}

Data hasil yang sudah diproses selanjutnya masuk pada tahap ekstraksi ciri menggunakan FFT. Data suara akan diproses terlebih dahulu untuk menentukan framing melalui tahapanframing dalam milisekon, sebagai contoh framing dalam $1000 \mathrm{~ms}$.

\subsection{Identifikasi}

Setelah didapat ciri, maka proses berlanjut pada identifikasi dengan menggunakan autokorelasi yang berfungsi untuk menentukan kesamaan jarak antara panjang pola yang sama. Setiap frame dari sinyal setelah melalui proses windowing dan ekstraksi ciri kemudian dilakukan analisis autokorelasi untuk menentukan nilai tertinggi yang paling cocok. Pada tahap ini potongan reff bagian pertama akan dilakukan pencocokan dengan input data berupa lagu utuh yang sudah dilakukan ekstraksi ciri. Kemudian sistem akan mencari nilai kecocokan yang paling tinggi antara sampel awal potongan reff pertama lagu dengan lagu utuh itu sendiri.

$$
r_{1}(m) \sum_{n=0}^{N-1-m} \delta_{l}(n) \cdot \delta_{l}(n+m) ; m=0,1,2, \ldots, p
$$

\subsection{Akurasi dan Error}

Pengujian sistem dilakukan dengan menggunakan parameter akurasi dan error. Akurasi merupakan ukuran ketelitian sistem dalam memisahkan reffinput lagu yang diberikan sehingga menghasilkan output yang benar. Akurasi sistem secara keseluruhan dapat ditulis sebagai berikut :

$$
\text { Akurasi }=\frac{\text { Jumlah data benar }}{\text { Jumlah data keseluruhan }} \times 100 \%
$$

Sedangkan error merupakan tingkat kesalahan sistem dalam memisahkan reffinput lagu yang diberikan terhadap jumlah data lagu secara keseluruhan. Error secara matematis dapat ditulis sebagai berikut

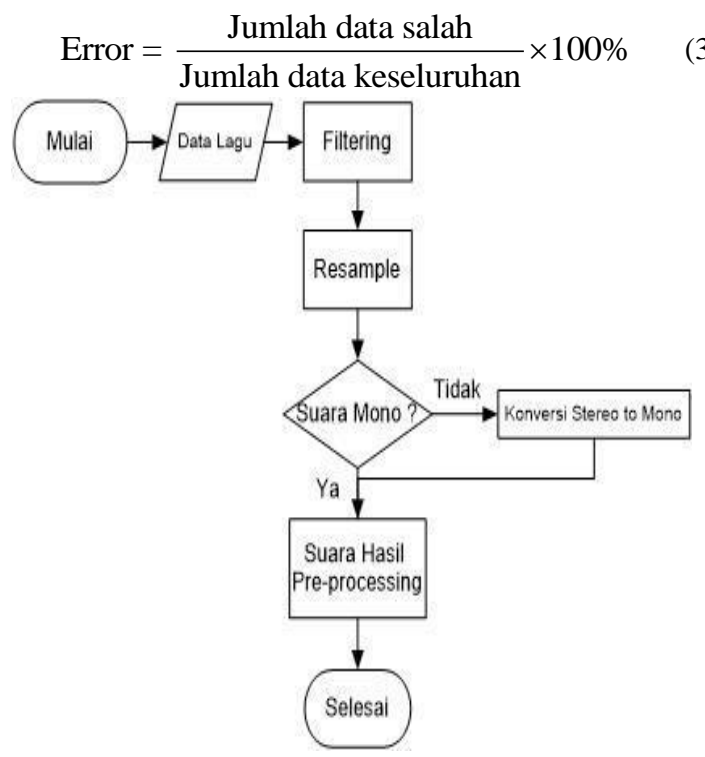

Gambar 5. Flowchart Pre-Processing 


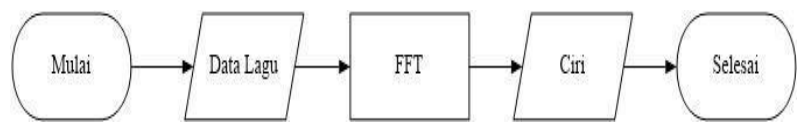

Gambar 6. Diagram Ekstraksi Ciri

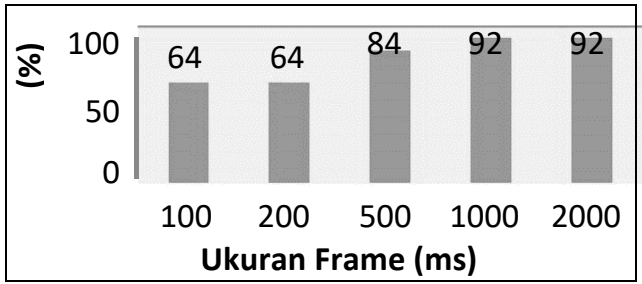

Gambar 7. Pengaruh Ukuran Frame pada Akurasi Data Lagu

\section{Pengujian Sistem dan Analisis}

Pada bab ini dilakukan beberapa pengujian terhadap sistem yang telah dirancang.Untuk mengetahui performansi sistem yang telah dirancang, maka dilakukan pengujian terhadap sistem dengan skenario pengujian.

Pengujian dan analisis pengaruh ukuranframe pada ekstraksi ciri terhadap akurasi outputsystem. Pengaruh Ukuran Frame Terhadap Akurasi Output Sistem. Dalam skenario ini dilakukan pengujian pengaruh ukuran frame pada proses ekstraksi ciri. Dalam pengujian digunakan data 25 lagu yang dikelompokkan menjadi 5 yaitu instrument, pop, jazz, edm, dan rock.Dari gambar 7. Didapat nilai ukuran frame yang baik untuk seluruh lagu yaitu $1000 \mathrm{~ms}$ dan 2000 ms.Dan ukuran frame yang terbaik yaitu ukuran frame 2000 ms karena waktu komputasi pencarian reff yang lebih baik dari $1000 \mathrm{~ms}$.

Hal ini disebabkan semakin besar ukuran frame maka semakin banyak ciri yang dihasilkan sehingga akurasi semakin besar.

\section{Kesimpulan}

Berdasarkan hasil simulasi, pengujian serta analisa yang dilakukan maka dapat ditarik kesimpulan bahwa, pada pengujian yang sudah dilakukan dapat disimpulkan bahwa dengan menggunakan sistem ini FFT dapat bekerja dengan baik dalam menentukan reff lagu.Sistem dapat menampilkan potongan reff lagu kedua dan ketiga secara langsung setelah menentukan posisi reff pertama.Pada pengujian yang sudah dilakukan,sistem dapat menentukan reff lagu dengan baik dengan akurasi sebesar $92 \%$ pada ukuran frame $1000 \mathrm{~ms}$ dan $2000 \mathrm{~ms}$.Semakin besar ukuran frame maka semakin tinggi nilai akurasi sistem yang didapatkan, hal ini disebabkan karena semakin banyak ciri yang dihasilkan.

\section{Daftar Pustaka}

[1] Rizka, A. (2015). Analisis dan SimulasiKlasifikasi Judul Lagu dari Senandung Manusia Menggunakan Ekstraksi Ciri Fast Fourier Transform. Bandung: UniversitasTelkom.

[2] Brigham, E. O. (1988). The Fast FourierTransform and Its Application. Singapore:Prentice Hall, Inc.

[3] Renny Rahmawati, Rita Magdalena, I Nyoman Apraz Ramatryana \{2016), Perbandingan Dan Analisis $K$ - Nearest Neighbor Dan Linear Discriminant Analysis Untuk Klasifikasi Genre Musik, eProceedings of Engineering vol 3 no. 2 (2016) Universitas Telkom 